\title{
Distribution of epiphytic dinoflagellates on macroalgae in the coast of Pernambuco, Northeast Brazil
}

\author{
Nayana Buarque Antão da Silva ${ }^{1 *}$, Manuel de Jesus Flores Montes²,

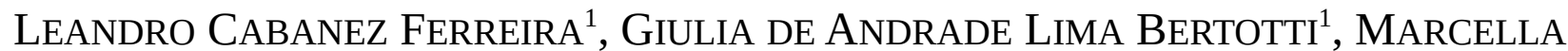

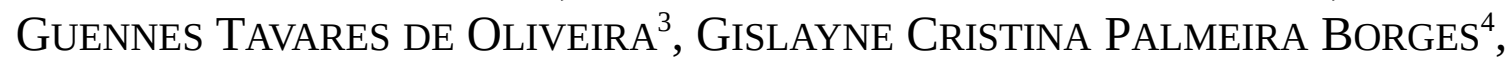 \\ JAMERSON HENRIQUE Freitas dA SILVA², AdILMA DE LOURDES MONTENEGRO \\ COCENTINO $^{5}$, MARIA DA GLÓRIA GONÇALVES DA SILVA CUNHA ${ }^{1}$ \\ ${ }^{1}$ Department of Oceanography/Phytoplankton Laboratory, Federal University of Pernambuco, Av. Prof. \\ Moraes Rego, 50670-901, Recife, Pernambuco, Brazil; \\ ${ }^{2}$ Department of Oceanography/Laboratory of Chemical Oceanography, Federal University of Pernambuco,
} Av. Prof. Moraes Rego, 50670-901, Recife, Pernambuco, Brazil;

${ }^{3}$ Department of Botany - PPGEtno/Plankton Ecology Laboratory, Federal Rural University of Pernambuco, Rua Dom Manuel de Medeiros, s/n - Dois Irmãos, Recife - PE, 52171-900;

${ }^{4}$ Department of Oceanography/Laboratory of Bentos, Federal University of Pernambuco, Av. Prof. Moraes Rego, 50670-901, Recife, Pernambuco, Brazil;

${ }^{5}$ Department of Oceanography/Macroalga Laboratory, Federal University of Pernambuco, Av. Prof. Moraes Rego, 50670-901, Recife, Pernambuco, Brazil.

*Corresponding author:n.naay@hotmail.com

\begin{abstract}
Epiphytic dinoflagellates on macroalgae were studied to identify the floristic composition and quantitative variations as a function of environmental variables at beaches with different degrees of urbanization. Ten species of dinoflagellates were identified, with a predominance of small individuals of the class Dinophyceae, Gymnodinium sp., Ostreopsis cf. ovata Fukuyo, Prorocentrum lima (Ehrenberg) F. Stein, Protoperidinium sp., and Scrippsiella spinifera G. Honsell \& M. Cabrini. Pedra de Xaréu beach presented higher richness and abundance, with Ostreopsis cf. ovata and P. lima standing out as exclusive of this beach, with higher abundance on Hypnea musciformis (Wulfen) J. V. Lamouroux (488 and 408 cells g ${ }^{-1}$, respectively) and Sargassum sp. (34 and 90 cells g ${ }^{-1}$, respectively), in March/2018. At Pina beach, Gymnodinium sp. and S. spinifera were the dominant species, with records of 132 cells g${ }^{1}$ (February/2018) and 40 cells g $^{-1}$ (August/2017) on Palisada perforata (Bory) K. W. Nam. The specific diversity was low, ranging from 0 to 2.27 bits.cell $^{-1}$, with the lowest values corresponding to the dominance of S. spinifera and Gymnodinium sp. Favorable environmental conditions such as high temperature and salinity may be correlated with the abundance of potentially toxic dinoflagellates and the significant variation in phosphate proved the difference in anthropic impact on the beaches, highlighting the presence and absence of some species of dinoflagellates in macroalgae.
\end{abstract}

Key words: beaches, microalgae, nutrients, phototrophic, toxicity.

Resumo: Distribuição de dinoflagelados epifíticos em macroalgas no litoral de Pernambuco, nordeste do Brasil. Dinoflagelados epifíticos em macroalgas foram estudados para identificar a composição florística e as variações quantitativas em função das variáveis ambientais, em praias com diferentes graus de urbanização. Foram identificadas 10 espécies de dinoflagelados, com predominância de pequenos indivíduos da classe Dinophyceae, 
Gymnodinium sp., Ostreopsis cf. Ovata Fukuyo, Prorocentrum lima (Ehrenberg) F. Stein, Protoperidinium sp. e Scrippsiella spinifera G.Honsell \& M.Cabrini. Pedra de Xaréu apresentou maior riqueza e abundância, com destaque para Ostreopsis cf. ovata e P. lima como exclusivas, com maiores valores de abundância em Hypnea musciformis (Wulfen) J.V.Lamouroux (488 e $408 \mathrm{cel} / \mathrm{g}^{-1}$ ) e Sargassum sp. (34 e $90 \mathrm{cel} / \mathrm{g}^{-1}$ ), respectivamente, em março/2018. Pina, apresentou como espécies dominantes, Gymnodinium sp. e $S$. spinifera, registrando $132 \mathrm{cel} / \mathrm{g}^{-1}$

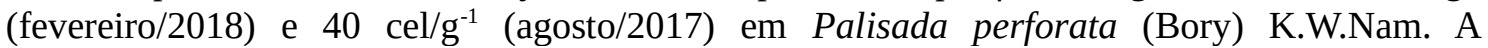
diversidade específica foi baixa, variando de 0 a 2,27 bits.cel $^{-1}$, com os menores valores correspondendo à dominância de S. spinifera e Gymnodinium sp. Condições ambientais favoráveis, como alta temperatura e salinidade, podem estar correlacionadas à abundância dos dinoflagelados potencialmente tóxicos e a variação significativa no fosfato comprovaram a diferença do impacto antrópico nas praias, destacando a presença e ausência de algumas espécies de dinoflagelados em macroalgas.

Palavras-chave: praias, microalgas, nutrients, fototróficos, toxicidade.

\section{Introduction}

Marine microalgae are represented by a group of highly diversified organisms that have chlorophyll $a$ as their main pigment and play a significant role in the dynamics of primary productivity, nutrient cycling and carbon transport. Their representatives occur in the water column, on the surface of sediments, and in artificial and natural substrates, standing out as the main elements in the trophic processes of aquatic ecosystems (Sournia 1978).

Several species of microalgae are epiphytic, that is, they live associated with macroalgae and marine angiosperms, forming a community attached to these natural substrates. In this relationship, the epiphytes benefit from the structure on which they can grow and the nutrients released by the macrophytes that they consume (Hauxwell et al. 2001). These epiphytes include representatives of all microalgal phyla, but diatoms, cyanobacteria, and dinoflagellates are typically the dominant groups (Macintyre et al. 1996).

Dinoflagellates are eukaryotic, unicellular protists widely distributed in marine environments, eventually occurring in limnic and mixohaline environments. The phylum is composed of approximately 2000 species (Tomas 1997) with epiphytic and also epibenthic habit, inhabiting several substrates such as mollusc carapaces (Gómez 2009), sponges (Hill et al. 2011), red mangrove (Marcano 2011), and corals (Costa et al. 2001).

Marine macroalgae have also been considered good substrates for the installation of epiphytic dinoflagellates and these assemblages represent an important component in tropical and subtropical regions (Gómez del Prado et al. 2011). Several epiphytic species belonging to the genera Amphidinium, Coolia, Gambierdiscus, Ostreopsis, and Prorocentrum are producing toxins (Faust et al. 1999, Laza-Martinez et al. 2011) that may cause a series of neurological, cardiovascular, and gastrointestinal problems (Lassus 1988, Cembella 2003, Selina et al. 2014).

Dinoflagellate communities growing as epiphytes on macroalgae may show variations according to different types of macroalgal architecture and high surface-to-volume ratio (Okolodkov et al. 2007, Totti et al. 2010, Okolodkov et al. 2014). According to Chung \& Lee (2008) and Totti et al. (2009), algae with highly branched or thin thalli provide a greater number of microhabitats, offering several opportunities for colonization of erect forms, while thalli with flat, smooth or foliose surfaces provided a better substrate for adnate forms.

The variability of epiphytic dinoflagellates has also been attributed to natural and anthropogenic changes, since macroalgal assemblages are affected by factors such as temperature, turbulence, transparency, nutrients, waves, cold fronts, hurricanes, among others (Taylor 1985, Diogene 1992). Grzebyk et al. (1994) analyzed the spatial distribution of ciguateric dinoflagellates in the coral reef lagoon of the island of Mayotte in the Indian Ocean and observed that red algae supported greater abundances and stimulated the growth of Ostreopsis ovata. In a study on the Northwestern coast of Cuba, Delgado et al. (2006) observed that the environmental conditions in summer (higher temperature, more nutrients, greater water transparency and low wind intensity) were suitable for the development of macroalgae, which serve as a substrate for potentially toxic dinoflagellates, and possibly the main vector for the spread of ciguatera along the coast of Cuba. Cohu et al. (2013) studied the environmental factors that regulate or influence 
the growth of Ostreopsis along the French and Italian coasts and found seasonal variations in abundance correlated with seawater temperature, with the ideal temperature for growth varying from $23{ }^{\circ} \mathrm{C}$ to $27.5^{\circ} \mathrm{C}$.

In the state of Pernambuco (Northeast Brazil), research on microalgae associated with marine macrophytes has been carried out only with epiphytic diatoms on angiosperms (Pacobahyba et al. 1991, Eskinazi-Leça et al. 2003) and macroalgae, addressing the biodiversity and growth variation of diatoms on different substrates (Costa et al. 2014, Costa et al. 2016). Studies on the flora of epiphytic dinoflagellates are rare, but the planktonic flora is reasonably known, both qualitatively and quantitatively/ecologically, being characterized by the presence of the genera Ceratium, Pyrocystis and Ornithocercus (Passavante 1979, Koening \& Macedo 1999, Koening \& Lira 2005).

Research on the biodiversity and structure of epiphytic dinoflagellates is necessary to better understand the relationships between species and different hosts. Thus, this study aimed to identify qualitative and quantitative variations of epiphytic dinoflagellates on several macroalgae in the coast of Pernambuco and evaluate these variations as a function of environmental variables in beaches with different degrees of urbanization.

\section{Materials and Methods}

Study area: The coast of Pernambuco is located between the parallels $7^{\circ} 33^{\prime}$ to $8^{\circ} 55^{\prime} \mathrm{S}$ and the meridians $34^{\circ} 49^{\prime}$ to $35^{\circ} 11^{\prime} \mathrm{W}$, within the range of hot and humid tropical climate, As' type, according to the Koppen classification (Andrade \& Lins 1971, Nimer 1989). According to the distribution of rainfall, there are two annual periods, dry and rainy, influenced by cold fronts from the South and Southeast of the country. The dry period comprises the months between September and February, with a mean rainfall of $60.2 \mathrm{~mm}$ and air temperature around $27^{\circ} \mathrm{C}$. The rainy period extends between March and August, with a mean rainfall of $301.5 \mathrm{~mm}$ and air temperature around $25.4{ }^{\circ} \mathrm{C}$ (Aragão 2004, Melo et al. 2014). The mean annual air temperature is around $28{ }^{\circ} \mathrm{C}$ and the salinity of sea water around 36 (Macedo et al. 2004).

The Pernambuco continental shelf is considered one of the smallest on the Brazilian coast - only $187 \mathrm{~km}$ long and 35-42 km wide - with the bottom covered by terrigenous sediments. Sandstone and coral reef formations, in large irregular patches that extend in lines parallel to the coast, emerge in some points or remain partially immersed (Guerra \& Manso 2004).

Two locations were selected for collection of material, based on the action of anthropogenic factors, degree of urbanization, and different hydrodynamics (Fig. 1):

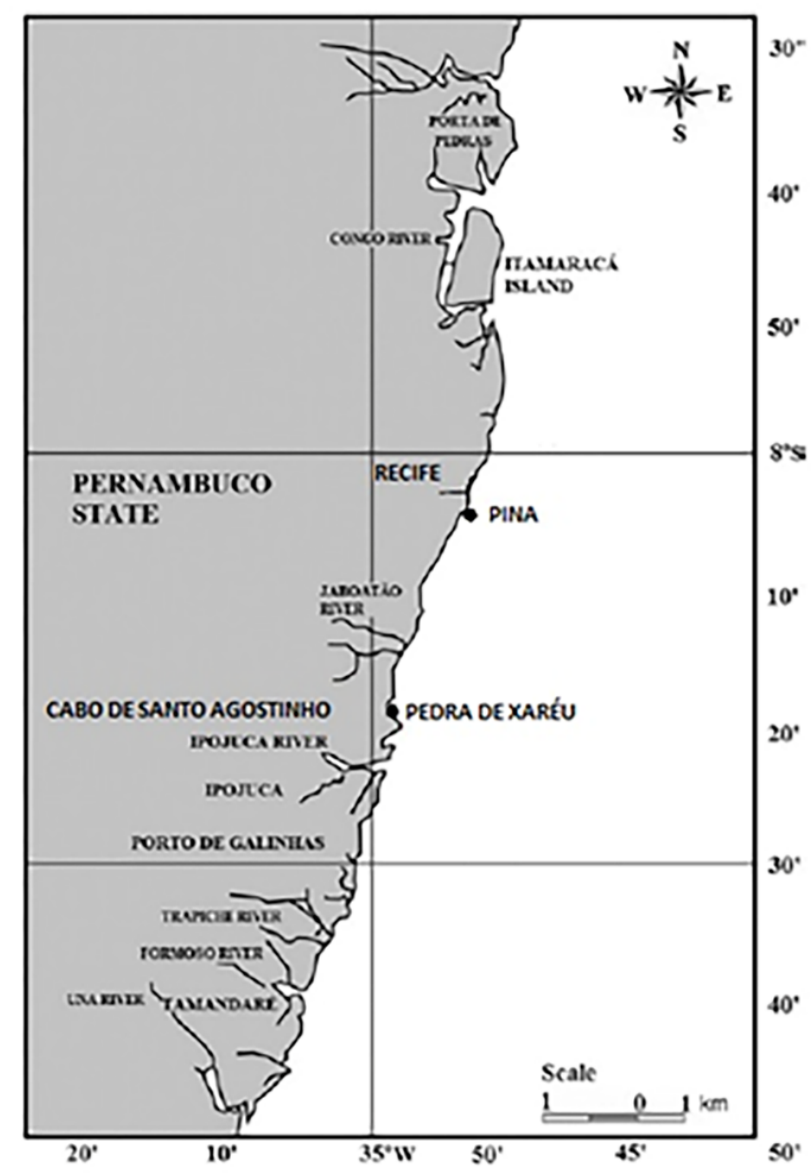

Figure 1. Study area with collection points on the beaches of Pina and Pedra de Xaréu (Pernambuco, Northeast Brazil).

1. Pina beach $\left(8^{\circ} 05^{\prime} 40^{\prime \prime} \mathrm{S}\right.$ and $\left.34^{\circ} 52^{\prime} 50^{\prime \prime} \mathrm{W}\right)$, with an extension of about $2 \mathrm{~km}$, located in the coastal zone of the city of Recife, is characterized by the presence of beach rocks which act as a natural protection system for the coastline. Reefs serve as a substrate for the development of an abundant algal flora and associated fauna (Guerra \& Manso 2004). The urban environment near the beach has medium to high density of buildings, with a long range of residential, commercial and entertainment buildings close to the beach, which favors intense human activity and anthropic impact (Orla 2001). It is in fact classified as a consolidated urbanization (CU) area (Vasconcelos 2016).

2. Pedra de Xaréu beach $\left(8^{\circ} 18^{\prime} 14^{\prime \prime} S\right.$ and $\left.34^{\circ} 56^{\prime} 45^{\prime \prime} \mathrm{W}\right)$, also known as Ponta de Pedras Pretas, 
is located in the municipality of Cabo, approximately $30 \mathrm{~km}$ south of Recife. This beach faces the North, unlike most beaches on the coast of Pernambuco that face the Southeast, and is about 1 $\mathrm{km}$ long. It has rocky shores of volcanic origin interspersed with sandy beaches, under the action of large waves (Accioly 1992, Muñoz 1993), being classified as an area in the process of urbanization (PU), with a low population density and little occupation (Vasconcelos 2016).

Collection and Analysis of Environmental Variables: Collections of environmental and biological variables were carried out in the mesolittoral zone of each beach, in the rainy season (July, August/2017 and $M a r c h / 2018$ ) and in the dry season (September/2017, January and February/2018).

Climatological data on wind direction and speed, air temperature $\left({ }^{\circ} \mathrm{C}\right)$, and rainfall $(\mathrm{mm})$ were obtained from the National Institute of Meteorology (INMET). The measurement of the water temperature was carried out in situ using a common alcohol thermometer and water samples were collected with the aid of a Kitahara bottle. Salinity was determined using the Morh-Knudsen method, described by Strickland \& Parsons (1972). Dissolved nutrient salt concentrations were determined as follows: nitrite and nitrate according to Papaspyrou et al. (2014); ammonia according to Bower \& HolmHansen (1980); phosphate according to Strickland \& Parsons (1972); and silicate according to Grasshoff et al. (1983). Dissolved oxygen concentrations were determined by the modified Winkler method described by Strickland \& Parsons (1972), and the $\mathrm{pH}$ was determined by the spectrophotometric method (Dickson et al. 2007).

Collection and Analysis of Biological Variables: Five species of macroalgae belonging to the phyla Chlorophyta, Phaeophyta and Rhodophyta were chosen in each beach according to their greater representation in the sites and morphofunctional differences of the individuals (Table I).

Specimens of macroalgae (in duplicate) were carefully removed from the substrate, with the aid of spatulas, placed in plastic bags, packed in Styrofoam with ice and taken to the Phytoplankton Laboratory of the Department of Oceanography (UFPE). Then, they were weighed (15 g of wet weight) and placed in plastic pots with a volume of $30 \mathrm{~mL}$ of water from the collection site, previously filtered (glass fiber filter, $47 \mathrm{~mm}$ diameter, $0.45 \mu \mathrm{m}$ pore size). Subsequently, each pot was manually shaken for 2 minutes in order to displace the epiphytic flora (Vila et al. 2001). The macroalgae were removed from the pots and the suspension was fixed with lugol solution ( $2 \%$ concentration).

In total, 60 samples were analyzed. The qualitative analysis of dinoflagellates was performed with the aid of an optical microscope (Zeiss) at 20x magnification and a TCA-1.31C camera attached to record the species found. The species were identified with the aid of the following bibliographies: Balech 1988, Hoppenrath et al. 2009, Kraberg et al. 2010.

To quantify the cells, the content of each sample was poured into $10-\mathrm{ml}$ cuvettes, for sedimentation for 24 hours. Subsequently, the cuvettes were analyzed according to the method of Utermöhl (1958), using an inverted microscope (Zeiss, AXIOVERT) at 20x magnification. Abundance was expressed in macroalgae wet weight cel g-1 (Gillespie et al. 1985).

Species diversity was calculated using the Shannon-Weiner index (Shannon 1948) and classified according to Margalef (1978) and the evenness ( $\left.\mathrm{J}^{\prime}\right)$ was calculated according to Pielou (1967). Species richness was determined by the number of taxa found in the sampling units. The specific diversity and evenness indices were analyzed using the Primer 6 software.

Statistical analysis: To determine the occurrence of significant differences between the beaches of Pina and Pedra de Xaréu (spatial variation), the rainy and the dry period (seasonal variation), and between macroalgal species (substrate), the data were submitted to the non-parametric Mann-Whitney and Kruskal-Wallis tests, and p values $<0.05$ were considered significant. All tests were performed using the BioEstat 5.3 software.

A Principal Component Analysis (PCA) was performed to elucidate the relationships between the most frequent epiphytic dinoflagellate species and the environmental variables (temperature, salinity, dissolved oxygen, nutrients, and $\mathrm{pH}$ ). To perform the PCA, the original data were arranged in the form of a matrix of order $15 \times 15$, in which the 15 determinations performed and the 15 variables evaluated were represented. This data set was centered on the mean and scaled according to the variance of the results, due to the different response intensities found for the considered variables. The analyses were performed using the STATISTICA software (Version 7.0) and the significance level considered for the tests was $\mathrm{p}<0.05$.

\section{Results}

Environmental variables: Climatological data on wind speed and direction showed that southeast 
Table I: Macroalgae collected (2017-2018) on the beaches of Pina and Pedra de Xaréu (Pernambuco, Northeast Brazil).

\begin{tabular}{lll}
\hline \hline Species & Phyllum & Beach/Month \\
\hline Bryopsis sp.* & Chlorophyta & P1/ Every month \\
Ulva sp.* & Chlorophyta & P1/ Every month \\
Dictyopteris delicatula J.V.Lamouroux & Phaeophyta & P2/ Jul, Aug and Sept \\
Padina sp. & Phaeophyta & P2/ Jan, Feb and Mar \\
Sargassum sp.* & Phaeophyta & P2/ Every month \\
Amansia sp. & Rhodophyta & P1/ July \\
Bryothamnion triquetrum (S.G.Gmelin) M.Howe * & Rhodophyta & P2/ Every month \\
Chondracanthus acicularis (Roth) Fredericq & Rhodophyta & P1/ Jan, Feb and Mar \\
Corallina officinalis Linnaeus & Rhodophyta & P1/ Jul, Aug and Sept \\
Digenea simplex (Wulfen) C.Agardh * & Rhodophyta & P2/ Every month \\
Hypnea musciformis (Wulfen) J.V.Lamouroux & Rhodophyta & P2/ Every month \\
Gracilaria sp.* & Rhodophyta & P1/ Every month \\
Palisada perforata (Bory) K.W.Nam & Rhodophyta & P1/ Aug, Sep, Jan, Feb and Mar \\
\hline
\end{tabular}

* = Dominant specie; P1 = Pina beach; P2 = Pedra de Xaréu beach; Jul = July; Aug = August; Sept = September; Jan = January; Feb = February; Mar = March.

winds predominated throughout the study period except in July (2017-2018) when south winds predominated, and November (2017), when east winds predominated. The monthly mean wind speed remained between 1.09 and $2.49 \mathrm{~m} \mathrm{~s}^{-1}$ and the monthly mean maximum wind speed peaked in July (2017) and August (2018), reaching 6.8 and $5.14 \mathrm{~m}$ $\mathrm{s}^{-1}$, respectively. The minimum speed values were recorded in May (2017) and April (2018). The mean air temperature remained between 24 and $27.5^{\circ} \mathrm{C}$ during the two years in which the samples were taken.

During the year 2017-2018, the studied region had an accumulated rainfall of $1942 \mathrm{~mm}$, with a mean of $258 \mathrm{~mm}$ during the rainy period and $66 \mathrm{~mm}$ during the dry period. Precipitation increased from March, with the highest accumulated rainfall (380.65 mm) recorded in April, and began to decrease from August, with the lowest accumulated rainfall (26.3 mm) in November (Fig. 2).

The water temperature and salinity values were similar in both beaches, with a mean temperature of $28.2^{\circ} \mathrm{C}$ at Pina beach and $29.2^{\circ} \mathrm{C}$ at Pedra de Xaréu beach, for the rainy season, and 30.7 and $29.8^{\circ} \mathrm{C}$ for the dry period, respectively. The

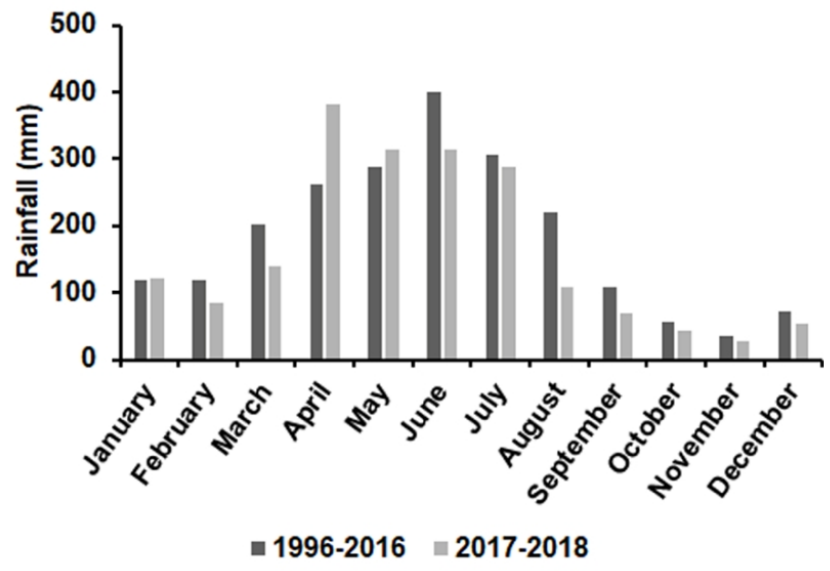

Figure 2. Distribution of rainfall in 2017-2018 and the historical series (1996-2016) for the coast of Pernambuco (Pernambuco, Northeast Brazil).

mean salinity was 33.5 and 36.2 in the rainy season, and 35.2 and 37.1 in the dry season, on Pina and Pedra de Xaréu beaches, respectively (Fig. 3a; Table II).

Nitrite concentrations remained low on the two beaches studied and with small variations, with a mean of 0.3 and $0.1 \mu \mathrm{mol} \mathrm{L^{-1 }}$ during the rainy season and 0.4 and $0.6 \mu \mathrm{mol} \mathrm{L}{ }^{-1}$ during the dry 

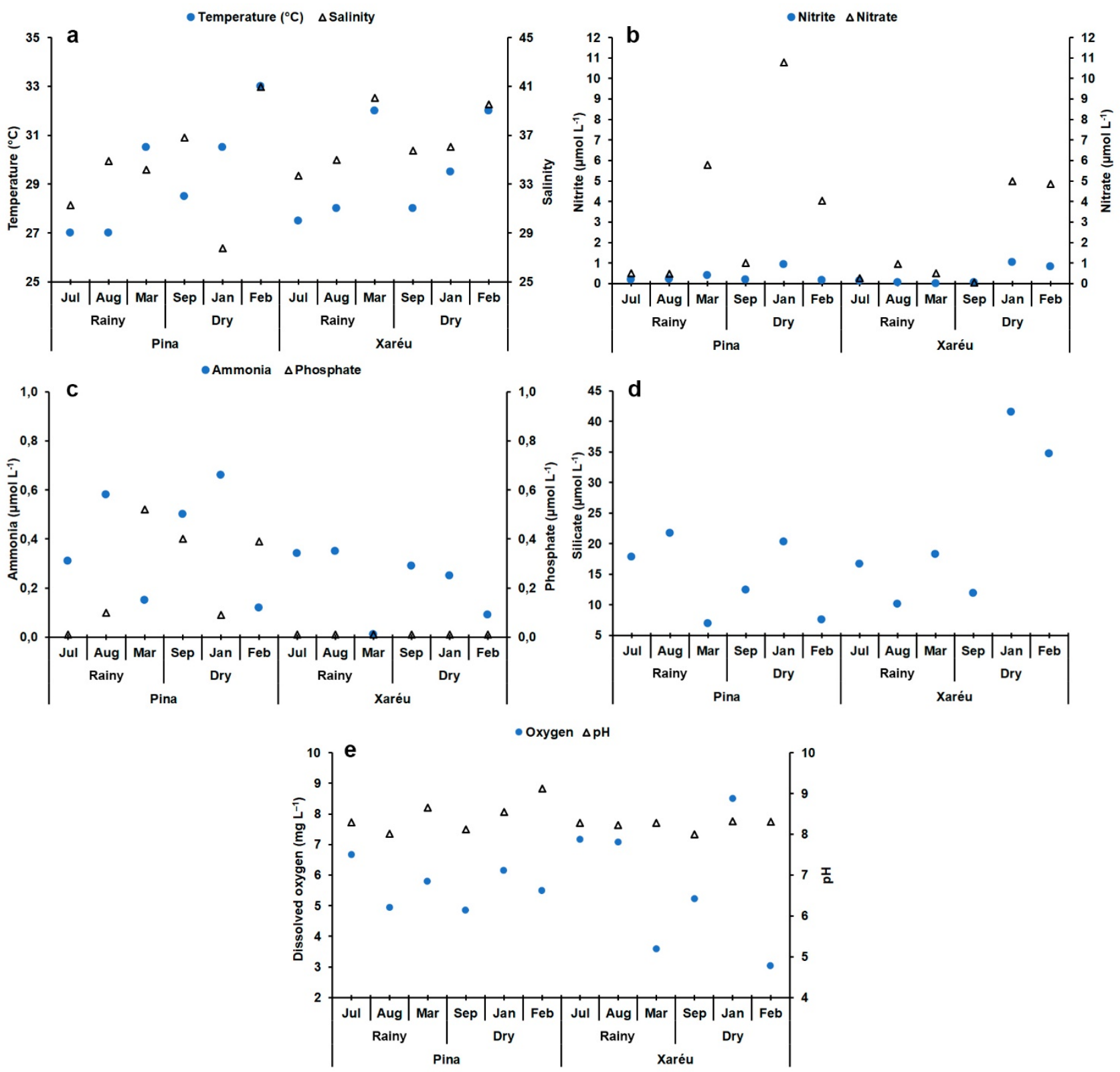

Figure 3. Variation of the environmental variables analyzed on Pina and Pedra de Xaréu beaches (Pernambuco, Northeast Brazil): (a) Temperature (C $\left.{ }^{\circ}\right)$ and Salinity; (b) Nitrite $\left(\mathrm{NO}_{2}\right)$ and Nitrate $\left(\mathrm{NO}_{3}\right)$; (c) Ammonia $\left(\mathrm{NH}_{3}\right)$ and Phosphate $\left(\mathrm{PO}_{4}\right)$; (d) Silicate $\left(\mathrm{Si}(\mathrm{OH})_{4}\right)$; (e) Dissolved oxygen (DO) and $\mathrm{pH}$.

season, to Pina and Pedra de Xaréu beaches, respectively. Nitrate had higher concentrations in the dry period, reaching a maximum value of 10.78 $\mu \mathrm{mol} \mathrm{L}^{-1}$ in January (2018) at Pina beach and 5 $\mu \mathrm{mol} \mathrm{L} \mathrm{L}^{-1}$ at Pedra de Xaréu beach, with means of 2.3

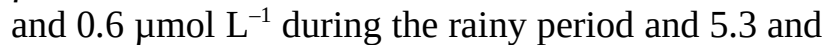
$3.3 \mu \mathrm{mol} \mathrm{L}{ }^{-1}$ during the dry period (Fig. 3b; Table II).

Ammonia and phosphate showed small variations between beaches and periods. The mean concentrations of ammonia were 0.3 and 0.2 in the rainy period and 0.4 and 0.2 in the dry period, at Pina and Pedra de Xaréu beaches, respectively. As for phosphate, Pina beach presented a mean concentration of $0.2 \mu \mathrm{mol} \mathrm{L}{ }^{-1}$ in the rainy period and $0.3 \mu \mathrm{mol} . \mathrm{L}^{-1}$ in the dry period. Pedra de Xaréu beach presented non-detectable values $\left(0.01 \mu \mathrm{mol} \mathrm{L}^{-1}\right)$ in all collection months (Fig. 3c; Table II).

The silicate contents were higher at Pedra de Xaréu beach, reaching a maximum value of 41.5 $\mu \mathrm{mol} \mathrm{L^{-1 }}$ in January (2018). Mean contents of 15.5 and $15 \mu \mathrm{mol} \mathrm{L} \mathrm{L}^{-1}$ were recorded during the rainy period and 13.4 and $23.9 \mu \mathrm{mol} \mathrm{\textrm {L } ^ { - 1 }}$ during the dry period at Pina and Pedra de Xaréu beaches, respectively (Fig. 3d; Table II). 
Table II: Descriptive statistics of environmental variables at Pina and Pedra de Xaréu beaches (Pernambuco, Northeast Brazil).

\begin{tabular}{|c|c|c|c|c|c|c|c|c|c|}
\hline \multirow[b]{2}{*}{$\begin{array}{l}\text { Environmental } \\
\text { Variables }\end{array}$} & \multicolumn{4}{|c|}{ Pina } & \multicolumn{4}{|c|}{ Xaréu } & \multirow[b]{2}{*}{$\begin{array}{l}\text { Spatial } \\
\text { p-value }\end{array}$} \\
\hline & Min & Max & Mean \pm SD & $\begin{array}{c}\text { Seasona } \\
\text { l } \\
\text { p-value }\end{array}$ & Min & Max & Mean \pm SD & $\begin{array}{c}\text { Seasonal } \\
\text { p-value }\end{array}$ & \\
\hline Temperature $\left({ }^{\circ} \mathrm{C}\right)$ & 27.00 & 33.00 & $29.42 \pm 2.35$ & 0.17 & 27.50 & 32.00 & $29.50 \pm 2.05$ & 0.5 & 0.87 \\
\hline Salinity & 27.77 & 40.96 & $30.21 \pm 3.99$ & 0.51 & 33.69 & 40.08 & $36.68 \pm 2.57$ & 0.51 & 0.33 \\
\hline Nitrite $\left(\mu \mathrm{mol} \mathrm{L}^{-1}\right)$ & 0.16 & 0.92 & $0.35 \pm 0.30$ & 0.51 & 0.01 & 1.04 & $0.35 \pm 0.46$ & 0.18 & 0.26 \\
\hline Nitrate $\left(\mu \mathrm{mol} \mathrm{L}{ }^{-1}\right)$ & 0.48 & 10.78 & $3.77 \pm 4.06$ & 0.27 & 0.05 & 5.00 & $1.94 \pm 2.34$ & 0.51 & 0.26 \\
\hline Ammonia $\left.(\mu \mathrm{mol} \mathrm{L})^{-1}\right)$ & 0.12 & 0.66 & $0.39 \pm 0.23$ & 0.82 & 0.01 & 0.35 & $0.22 \pm 0.14$ & 0.51 & 0.2 \\
\hline Phosphate $\left.(\mu \mathrm{mol} \mathrm{L})^{-1}\right) *$ & 0.01 & 0.52 & $0.25 \pm 0.21$ & 0.82 & 0.01 & 0.01 & $0.01 \pm 0.0$ & 1 & 0.007 \\
\hline Silicate $\left(\mu \mathrm{mol} \mathrm{L} \mathrm{L}^{-1}\right)$ & 6.90 & 21.70 & $14.45 \pm 6.42$ & 0.82 & 10.10 & 41.50 & $22.2 \pm 12.86$ & 0.27 & 0.42 \\
\hline Dissolved oxygen $\left(\mathrm{mg} \mathrm{L}^{-1}\right)$ & 4.86 & 6.66 & $5.65 \pm 0.70$ & 0.82 & 3.04 & 8.50 & $5.77 \pm 2.17$ & 0.82 & 0.52 \\
\hline pH & 8.01 & 9.12 & $8.46 \pm 0.41$ & 0.51 & 8.00 & 8.33 & $8.24 \pm 0.12$ & 0.51 & 0.33 \\
\hline
\end{tabular}

$*=\mathrm{p}<0.05$ (significant variation). $\min =$ minimum; $\max =$ maximum; mean $\pm \mathrm{SD}=$ mean \pm standard deviation.

The minimum value of dissolved oxygen was 3 mg. $\mathrm{L}^{-1}$ in February (2018), and the maximum value was 8.5 mg. $\mathrm{L}^{-1}$ in January (2018) at Pedra de Xaréu beach. A mean of $5.9 \mathrm{mg} . \mathrm{L}^{-1}$ during the rainy period and of $5.6 \mathrm{mg} . \mathrm{L}^{-1}$ during the dry period was recorded at the two beaches. The $\mathrm{pH}$ remained constant and alkaline in both beaches and both periods, ranging from 8 to 9.12 (Fig. 3e; Table II).

According to the statistical analysis, there was no significant seasonal and spatial variation in the environmental variables except for phosphate, which showed significant spatial variation ( $\mathrm{p}<0.05)$, with higher values at Pina beach (Table II).

Biological variables: At Pina beach, the most representative macroalgae were Bryopsis sp. and Ulva sp. (Chlorophyta), Amansia sp., Chondracanthus acicularis, Corallina officinalis, Gracilaria sp., and Palisada perforata (Rhodophyta). At Pedra de Xaréu beach, the most representative were Sargassum sp., Dictyopteris delicatula (Phaeophyta), Bryothamnion triquetrum, Digenea simplex, and Hypnea musciformis (Rhodophyta).

Ten species of epiphytic dinoflagellates were identified. Small individuals belonging to the class Dinophyceae were also present but not identified at a specific level due to the difficulty in identifying the athecate dinoflagellates, since their chloroplast morphology and cell shape undergo changes when the cells are fixed. However, these individuals were quantified for greater quantitative accuracy of estimates of the flora. Among the identified species, some are considered potentially toxic according to the published bibliography (Faust et al. 1999, LazaMartinez et al. 2011); however, during the collection period, no blooms occurred.

Five species of epiphytic dinoflagellates occurred in Pina beach, among which Gymnodinium sp., Heterocapsa sp., Prorocentrum sp. and Scrippsiella spinifera G.Honsell \& M.Cabrini stood out, occurring only in this beach, in addition to small dinoflagellates of the class Dinophyeceae. A greater diversity was found in Pedra de Xaréu beach (9 species), with notorious presence of Gymnodinium sp., Ostreopsis cf. ovata Y.Fukuyo, Prorocentrum lima, and Protoperidinium sp., besides small dinoflagellates of the class Dinophyceae (Fig. 4; Table III).

In term of total abundance, high values were observed in the month of March due to the abundance of Ostreopsis cf. ovata associated with the macroalgae $H$. musciformis and Sargassum sp., with 488 and 408 cells g ${ }^{-1}$, respectively, at Pedra de Xaréu beach (Fig. 5).

The greater representation of the phylum Rhodophyta provided greater diversity and abundance of epiphytes, reaching a total abundance of 144 cells $\mathrm{g}^{-1}$ on $P$. perforata at Pina beach in February (2018), and 520 cells g ${ }^{-1}$ on $H$. musciformis at Pedra de Xaréu beach in March (2018) (Fig. 5). Among the Chlorophyta, Ulva sp., dominant at Pina beach, stood out with the maximum abundance (108 cells $\mathrm{g}^{-1}$ ) of epiphytic dinoflagellates in March (2018) (Fig. 5). At Pedra de Xaréu beach, the phyla 


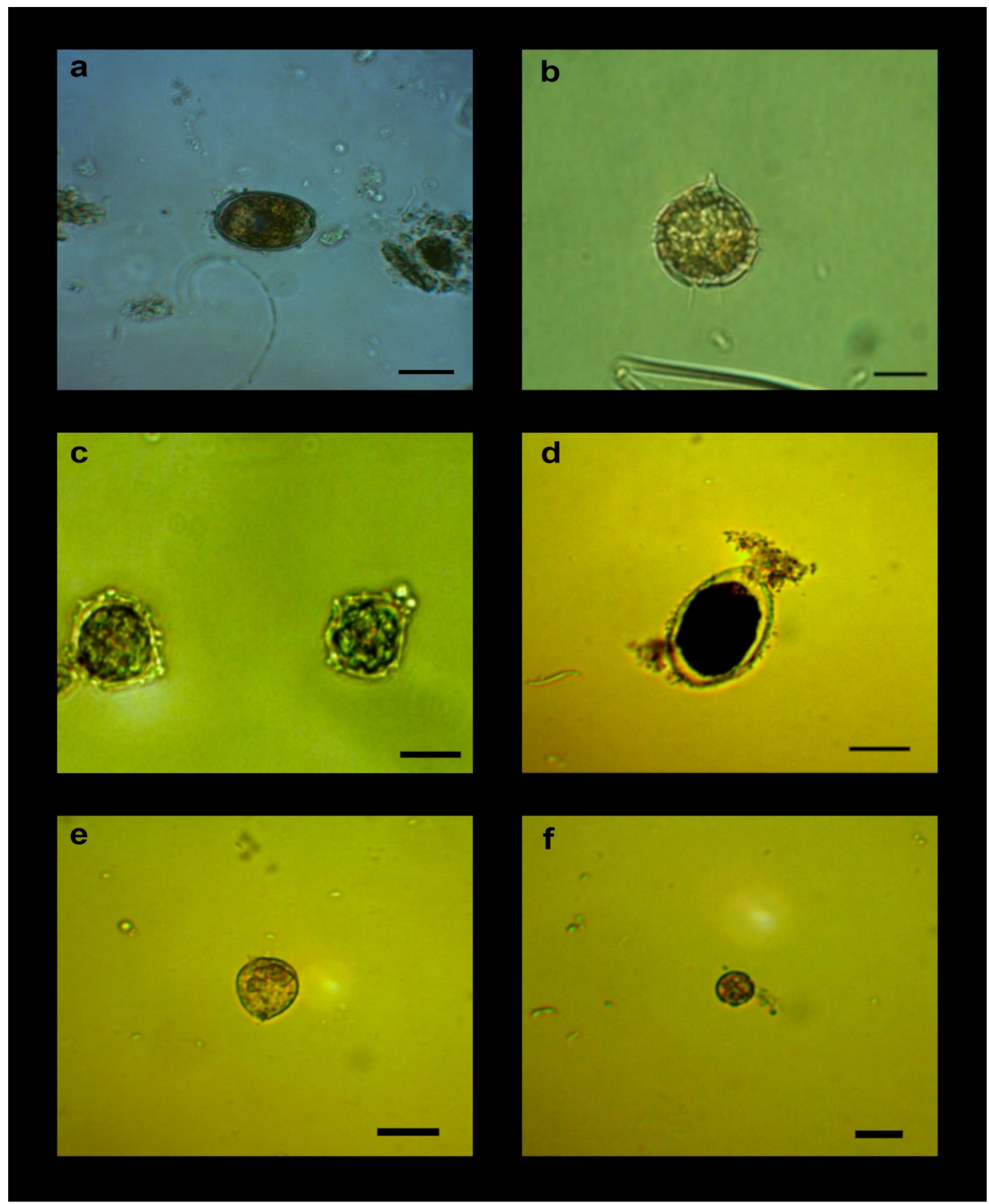

Figure 4. Most representative epiphytic dinoflagellates found on Pina and Pedra de Xaréu beaches (Pernambuco, Northeast Brazil). (a) Prorocentrum lima; (b) Protoperidinium; (c) Scrippsiella spinifera; (d) Ostreopsis cf. ovata; (e) Dinophyceae; (f) Gymnodinium sp. 

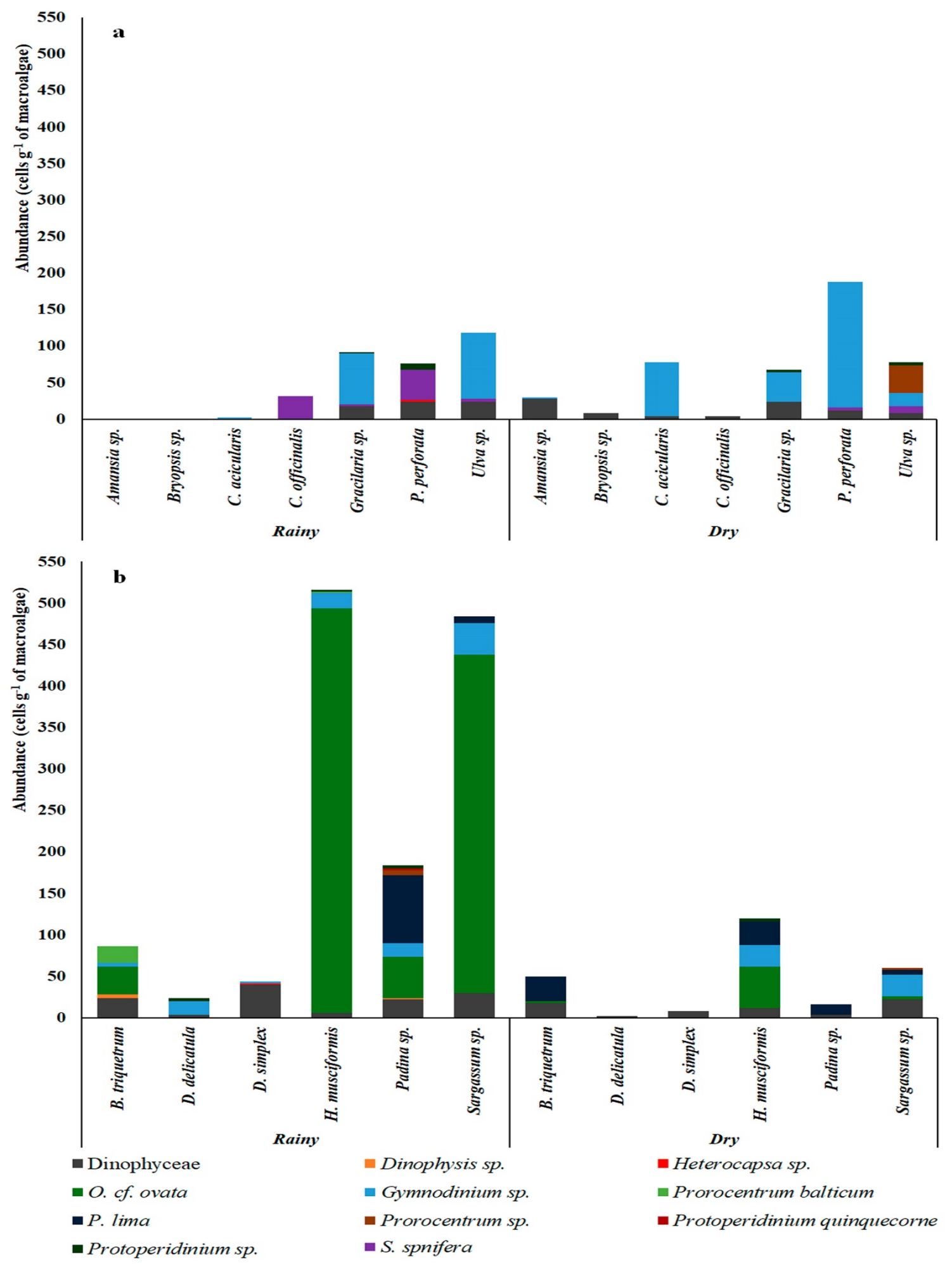

Figure 5. Seasonal dynamics of the abundance of epiphytic dinoflagellates associated with macroalgae on the beaches of Pina (a) and Pedra de Xaréu (b) (Pernambuco, Northeast Brazil). Rainy = Rainy season; Dry = Dry season. 
Table III: Epiphytic dinoflagellate species found on Pina and Pedra de Xaréu beaches (Pernambuco, Northeast Brazil).

\begin{tabular}{|c|c|c|c|c|c|}
\hline \multirow[b]{2}{*}{ Species } & \multicolumn{2}{|c|}{ Pina } & \multicolumn{2}{|c|}{ Xaréu } & \multirow[b]{2}{*}{ Toxicity } \\
\hline & Rainy & Dry & Rainy & Dry & \\
\hline Dinophysis sp. & & & $\mathrm{x}$ & & Some produce toxin. Cause DSP. \\
\hline Gymnodinium sp.* & $\mathrm{x}$ & $\mathrm{x}$ & $\mathrm{x}$ & $\mathrm{x}$ & $\begin{array}{c}\text { Some produce toxin. Cause CFP, PSP } \\
\text { and NSP. }\end{array}$ \\
\hline Heterocapsa sp. & $\mathrm{x}$ & & $\mathrm{x}$ & & Some produce toxin. \\
\hline Ostreopsis cf. ovata Y.Fukuyo* & & & $\mathrm{x}$ & $\mathrm{x}$ & Produce toxin. Cause CFP. \\
\hline $\begin{array}{l}\text { Prorocentrum balticum (Lohmann) } \\
\text { Loeblich }\end{array}$ & & & $\mathrm{x}$ & & Non toxic. \\
\hline $\begin{array}{l}\text { Prorocentrum lima (Ehrenberg) } \\
\text { F.Stein* }\end{array}$ & & & $\mathrm{x}$ & $\mathrm{x}$ & Produce toxin. Cause CFP and DSP. \\
\hline Prorocentrum sp. & & $\mathrm{x}$ & $\mathrm{x}$ & $\mathrm{x}$ & Some produce toxin. Cause DSP. \\
\hline $\begin{array}{l}\text { Protoperidinium quinquecorne (Abé) } \\
\text { Balech }\end{array}$ & & & $\mathrm{x}$ & & Non toxic. \\
\hline Protoperidinium sp.* & $\mathrm{x}$ & $\mathrm{x}$ & $\mathrm{x}$ & $\mathrm{x}$ & $\begin{array}{c}\text { Some produce toxin. Cause DSP and } \\
\text { AZP }\end{array}$ \\
\hline $\begin{array}{l}\text { Scrippsiella spinifera G.Honsell \& } \\
\text { M.Cabrini * }\end{array}$ & $\mathrm{x}$ & $\mathrm{x}$ & & & Non toxic. \\
\hline
\end{tabular}

* = Dominant species. Rainy = Rainy season; Dry = Dry season. Toxicity data were taken from published literature (Wright and Cembella 1998; Kim et al. 2009; Marchan-Álvarez et al. 2017). AZP = Azaspiracid Shellfish Poisoning; CFP = Ciguatera Fish Poisoning; DSP = Diarrhetic Shellfish Poisoning; NSP = Neurotoxic Shellfish Poisoning; PSP = Paralytic Shellfish Poisoning.

Rhodophyta and Phaeophyta presented a similar abundance of dinoflagellates, with higher values during the rainy period.

Epiphytic dinoflagellates did not show any significant preference for macroalgal species ( $p>$ 0.05); however, greater species richness (8 species) was found on the thalli of $B$. triquetrum and Padina sp.

Species diversity was very low, with indices ranging from 0.24 to 2.27 bits.cel $^{-1}$, classified as very low $\left(\leq 1\right.$ bit.cel $\left.^{-1}\right)$ in $75 \%$ of the samples. Regarding evenness, the values exceeded 0.5 in most of the samples analyzed, indicating that the taxa were evenly distributed at both beaches.

Regarding seasonal variation, the species Protoperidinium sp. showed significant variation ( $\mathrm{p}$ $<0.05)$ at Pedra de Xaréu beach. However, during the dry period the species Gymnodinium sp. showed significant variation $(\mathrm{p}<0.05)$ between beaches. Other species that also showed significant spatial variation $(\mathrm{p}<0.05)$ were: Ostreopsis cf. ovata, $P$. lima (Pedra de Xaréu beach) and S. Spinifera (Pina beach), being dominant and exclusive species on the beaches where they occurred (Table IV).

Principal Component Analysis: The PCA of all chemical $(n=8)$, physical $(n=1)$, and biological ( $=6$ ) variables showed that $60 \%$ of the data variance is explained by the 1-2 factorial plan (Axis 1 and Axis 2) (Fig. 6). The third component (Axis 3) represented 17\% (3 parameters) of the total sample (table V).

The main observations on axis 1 indicated a direct correlation between ammonia and S. spinifera. In contrast, they correlated inversely with temperature, salinity and the species Gymnodinium sp. On axis 2, there was a direct correlation between dissolved oxygen, phosphate and $\mathrm{pH}$, being inversely correlated with the species of the class Dinophyceae, Ostreopsis cf. ovata, P. lima, and Protoperidinium sp. A direct correlation was found on axis 3 , between the nutrient salts nitrite, nitrate, and silicate.

The first component of the PCA showed a strong association between the species $S$. spinifera and ammonia, demonstrating the importance of this nutrient for the cellular processes of the species and confirming the relationship of anthropogenic factors with the occurrence of this species only at Pina beach. The second component showed that the reduction of phosphate favored the development of the dominant and exclusive species in Pedra de Xaréu beach (Ostreopsis cf. ovata and P. lima). High temperature and salinity values in March (2018) directly influenced the increase in the abundance of epiphytic dinoflagellates during the rainy period. These factors are indicated to be of fundamental importance for the development of Dinophyceae, Ostreopsis cf. ovata, P. lima, and Protoperidinium sp. 
Table IV: Descriptive statistics of the most representative epiphytic dinoflagellates found on Pina and Pedra de Xaréu beaches (Pernambuco, Northeast Brazil).

\begin{tabular}{|c|c|c|c|c|c|c|c|c|c|}
\hline \multirow[b]{2}{*}{ Taxa } & \multicolumn{4}{|c|}{ Pina } & \multicolumn{4}{|c|}{ Xaréu } & \multirow[b]{2}{*}{$\begin{array}{l}\text { Spatial } \\
\text { p-value }\end{array}$} \\
\hline & $\min$ & $\max$ & mean \pm SD & $\begin{array}{c}\text { Seasonal } \\
\text { p-value }\end{array}$ & $\min$ & $\max$ & mean \pm SD & $\begin{array}{c}\text { Seasonal } \\
\text { p-value }\end{array}$ & \\
\hline Dinophyceae & 0 & 28 & $5.1 \pm 7.1$ & 0.58 & 0 & 38 & $6.7 \pm 9.1$ & 0.87 & 0.34 \\
\hline Scrippsiella spinifera * & 0 & 40 & $3.1 \pm 9.1$ & 0.7 & 0 & 0 & $0 \pm 0$ & NO & $0.00 *$ \\
\hline Ostreopsis cf. ovata * & 0 & 0 & $0 \pm 0$ & NO & 0 & 488 & $36.6 \pm 115.0$ & 0.99 & $0.00^{*}$ \\
\hline Gymnodinium sp. & 0 & 132 & $16.0 \pm 33.0$ & 0.09 & 0 & 34 & $5.0 \pm 9.5$ & 0.22 & 0.41 \\
\hline Prorocentrum lima * & 0 & 0 & $0 \pm 0$ & NO & 0 & 82 & $6.9 \pm 16.0$ & 0.57 & $0.00 *$ \\
\hline Protoperidinium sp.* & 0 & 4 & $0.60 \pm 1.4$ & 0.99 & 0 & 6 & $0.97 \pm 1.7$ & $0.03^{*}$ & 0.34 \\
\hline
\end{tabular}

$*=\mathrm{p}<0.05$ (significant variation). $\min =$ minimum; $\max =$ maximum; mean. $\pm \mathrm{SD} .=$ mean \pm standard deviation. $\mathrm{NO}=$ non ocurred.

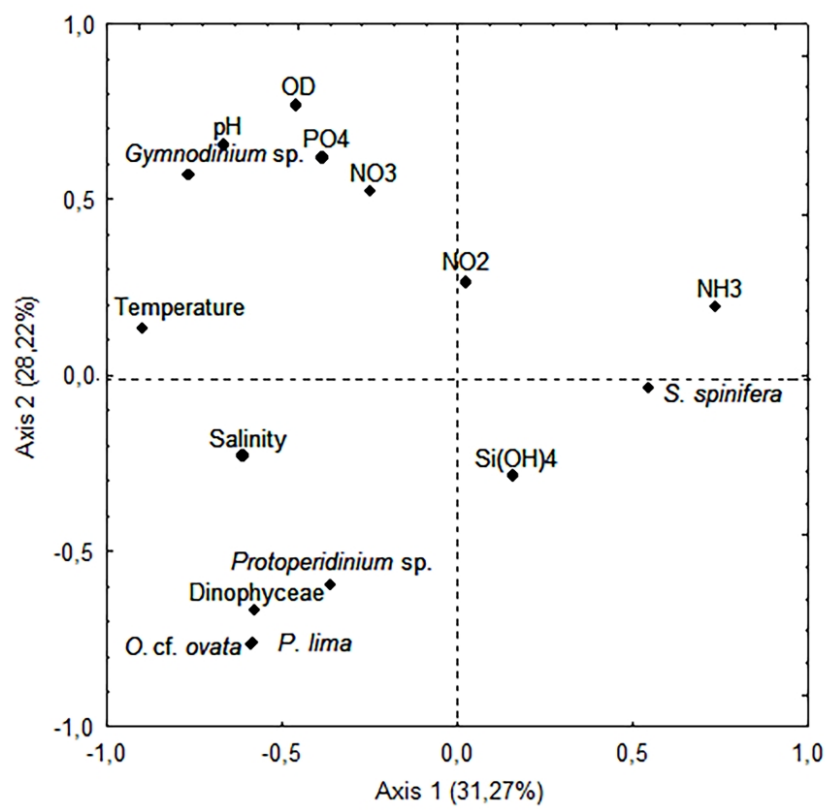

Figure 6. Principal Component Analysis (PCA) of chemical $(n=8)$, physical $(n=1)$ and biological $(n=6)$ variables on the beaches of Pina and Pedra de Xaréu (Pernambuco, Northeast Brazil).

\section{Discussion}

The environmental variables in the beaches studied were within the expected range for a tropical coastal region. Given the different degrees of urbanization and the action of anthropogenic factors, high levels of nitrate and higher levels of phosphate were observed at Pina beach. These nutrients have an important influence on this beach, especially during the dry period, due to increased tourist activity. In line with this, Ferreira et al. (2010) found lowest levels of phosphate during the rainy season on the beaches of Brasília Formosa, Boa Viagem, and Piedade.

The high levels of nitrogen compounds (ammonia, nitrite, and nitrate) favored the
Table V: Factor loadings of biological variables (dinoflagellates) and environmental variables to PCA components on the beaches of Pina and Pedra de Xaréu (Pernambuco, Northeast Brazil).

\begin{tabular}{|c|c|c|c|}
\hline Variable & $\begin{array}{c}\text { Axis 1 } \\
31,27 \% \\
\end{array}$ & $\begin{array}{c}\text { Axis 2 } \\
28,22 \% \\
\end{array}$ & $\begin{array}{c}\text { Axis } 3 \\
17 \% \\
\end{array}$ \\
\hline Temperature $\left({ }^{\circ} \mathrm{C}\right)$ & $-0,416^{*}$ & 0,065 & $-0,195$ \\
\hline Salinity & $-0,284^{*}$ & $-0,112$ & 0,161 \\
\hline \multirow{2}{*}{$\begin{array}{l}\text { Dissolved oxygen }\left(\mathrm{mg} \mathrm{L}^{-1}\right) \\
\text { Ammonia }\left(\mu \mathrm{mol} \mathrm{L}{ }^{-1}\right)\end{array}$} & $-0,215$ & $0,374 *$ & 0,160 \\
\hline & $0,340 *$ & 0,096 & $-0,061$ \\
\hline Nitrite $\left(\mu \mathrm{mol} \mathrm{L}{ }^{-1}\right)$ & 0,010 & 0,129 & $-0,589 *$ \\
\hline Nitrate $\left(\mu \mathrm{mol} \mathrm{L}^{-1}\right)$ & $-0,115$ & 0,254 & $-0,460 *$ \\
\hline Phosphate $\left(\mu \mathrm{mol} \mathrm{L}{ }^{-1}\right)$ & $-0,178$ & $0,301^{*}$ & 0,221 \\
\hline Silicate $\left(\mu \mathrm{mol} \mathrm{L}{ }^{-1}\right)$ & 0,072 & $-0,139$ & $-0,504 *$ \\
\hline pH & $-0,310$ & $0,320 *$ & $-0,042$ \\
\hline Dinophyceae & $-0,269$ & $-0,324 *$ & 0,089 \\
\hline Scrippsiella spinifera & $0,250^{*}$ & $-0,016$ & 0,087 \\
\hline Ostreopsis cf. ovata & $-0,271$ & $-0,369 *$ & 0,021 \\
\hline Gymnodinium sp. & $-0,356^{*}$ & 0,279 & 0,024 \\
\hline Prorocentrum lima & $-0,273$ & $-0,371^{*}$ & $-0,117$ \\
\hline Protoperidinium sp. & $-0,168$ & $-0,290 *$ & $-0,117$ \\
\hline
\end{tabular}

* values of greater correlation with the axis.

development of macroalgae, mainly of the phylum Chlorophyta, and consequently the abundance of $S$. spinifera and Gymnodinium sp. at Pina beach. Although ammonia did not show significant variation between beaches, small fluctuations in the levels of this nutrient were essential to increase the abundance of dinoflagellates. According to the ACP analysis, the positive association between ammonia and S. spinifera may have been attributed to the increase in microhabtats generated by the increase in the macroalgal community. This fact is reported by Delgado et al. (2006), in a study on the coast of 
Cuba, where found a relationship between nutrients and the two most abundant species (Gambierdiscus toxicus R. Adachi \& Y. Fukuyo and P. lima), but emphasized that environmental conditions in summer, with higher nutrients, were favorable to the development of macroalgae, providing a greater number of microhabitats for epiphytic dinoflagellates. However, it is also possible that the occurrence of the $S$. spinifera is favored by N/P ratio values closer to $16: 1$, but a longer and more detailed monitoring of the region is necessary to certify whether these parameters contribute to the appearance of that species.

According to the values obtained from DIN (dissolved inorganic nitrogen) and phosphate, it was possible to determine the Redfield ratio. With this information, we verified that Pedra de Xaréu beach presented values of N/P ratio much higher than Pina beach when compared to the same periods, justified by the low phosphate concentration presented in Pedra de Xaréu beach. Phosphate levels were undetectable at Pedra de Xaréu beach, confirming the different anthropic impacts acting on the two beaches. The beaches showed significant differences as to the presence of some species, confirming that Pedra de Xaréu beach is still in fact in process of urbanization. However, there were some records of high values of nitrogen compounds during the dry period, indicating that tourist activity also influences the increase in these levels.

Many studies have liked the increase in nutrient concentrations resulting from human activities to the increase in the frequency and intensity of harmful planktonic microalgae blooms (Hallegraeff 1993, Anderson et al. 2002, Heisler et al. 2008); however, the relationship between nutrients and epiphyte blooms is still inconclusive. Previous studies carried out on the Mediterranean coast of Spain (Vila et al. 2001), New Zealand (Shears \& Ross 2009), and Monaco (Cohu et al. 2011) found no direct correlation between the abundance of epibenthic dinoflagellates and nutrients.

The inverse correlation observed between phosphate and Ostreopsis cf. ovata and P. lima demonstrated that these species were favored by low levels of this nutrient $\left(0.01 \mu \mathrm{mol} . \mathrm{L}^{-1}\right)$ at Pedra de Xaréu beach. According to Rhodes et al. (2000), in a study in New Zealand, and Pearce et al. (2000), studying the east coast of Tasmania, high concentrations of nitrate and phosphate impede the growth of the species Ostreopsis siamensis Johs. Schmidt, corroborating what was observed in the present study. However, as a factor that makes an important contribution to blooming events of epiphytic dinoflagellates, temperature shows a strong relationship with the development of many species. This was also observed by Cohu et al. (2013) in the Mediterranean Sea where the blooming of Ostreopsis cf. ovata was related to increased temperature and decreased dissolved oxygen.

The highest abundance of dinoflagellates was related to the highest temperature values, which coincided with the highest salinity values and favored the proliferation of Ostreopsis cf. ovata. This relationship is consistent with the study by Mangialajo et al. (2011) on the Mediterranean coast of Spain, in which higher densities of epibenthic dinoflagellates were recorded during the months with higher temperatures. In eastern Tasmania, Pearce et al. (2001) also found this relationship, noting a decline in the number of dinoflagellates during winter.

Given the sampling effort of the present study, the abundance and diversity of species of epiphytic dinoflagellates were low (11 taxa in 60 samples), but with a high species richness, taking into account other works conducted with this assemblage. Okolodkov et al. (2007) reported low diversity (17 species in 221 samples) in the assemblage of epibenthic dinoflagellates in the Veracruz reef zone, in the Gulf of Mexico, but high abundance values. In a study in the coastal waters of Hawaii, Parson and Preskitt (2007) also observed low diversity (26 species in 369 samples) and high abundance values.

The dominance of Ostreopsis cf. ovata, the major component of the total epiphyte abundance during the study, was also reported in the Caribbean Sea, Cuba (Moreira et al. 2012), and in the northwestern Sea of Japan, Russia (Selina et al. 2014). Blooms of species of the genus Ostreopsis have been reported in other studies, as Vila et al. (2001) in the Mediterranean Sea, where the values of Ostreopsis sp. reached $5.9 \times 10^{5}$ cells $\mathrm{g}^{-1}$ on the macroalgae Halopteris scoparia (Linnaeus) Sauvageau. Some of the more intense blooms occurring among species of this genus worldwide were reported by Shears \& Ross (2009) in New Zealand, with the species $O$. siamensis reaching a maximum abundance of $1.4 \times 10^{6}$ cells g ${ }^{-1}$.

In Brazil, studies on epiphytic dinoflagellates are still recent and scarce. However, some laboratory studies with isolated strains of Ostreopsis cf. ovata, P. lima, Prorocentrum sp., Coolia malayensis Leaw, P.-T.Lim \& Usup, and Amphidinium sp. from Armação de Búzios and Arraial do Cabo, Rio de 
Janeiro, showed that higher temperature values stimulated the growth of all species and that higher temperatures, between 20 and $26{ }^{\circ} \mathrm{C}$, favored the growth of Ostreopsis cf. ovata (Nascimento \& Corrêa 2010). This fact was also observed in the present study, which, despite not having shown significant variation, a small rise in temperature, together with salinity and other favorable factors, provided good conditions for the development of Ostreopsis cf. ovata and P. lima. at Pedra de Xaréu beach.

The dominance and abundance of were also related to the codominance of In a study carried out on the northeast coast of Brazil, De' Carli (2014) also reported the dominance and higher abundance values of Ostreopsis cf. ovata and P. lima. Okolodkov et al. (2007) found the dominance of $P$. lima to be often associated with the dominance of Amphidinium cf. carterae Hulburt, Coolia monotis Meunier and Ostreopsis heptagon D. R. Norris, J. W. Bomber \& Balech, which may indicate that these potentially toxic species are almost always forming associations (Carlson \& Tindall 1985).

Although salinity did not show a significant seasonal variation, the highest values were found in the months of lower rainfall, with strong characteristics of dry season. Salinity and temperature were fundamental for the increase in the abundance of dinoflagellates except for S. spinifera, which was inversely correlated with the two variables. However, a direct correlation of the growth of Ostreopsis cf. ovata isolated from the Adriatic Sea with increased salinity was observed in laboratory experiments by Pezzolessi et al. (2012), which is in agreement with what was observed in the present study for most species of dinoflagellates.

Blooms of Ostreopsis cf. ovata are recorded both in coastal and oceanic regions. In Brazil, there are records of blooms in Arraial do Cabo, Rio de Janeiro, in the summers of 1999 and 2002, causing the poisoning and death of sea urchins (Granéli et al. 2002; Ferreira 2006). In Santa Catarina, on the beaches of Penha and Bombinhas (Tibiriçá et al. 2010) and in Bahia (Menezes et al. 2010), blooms resulted in the emergence of various symptoms among bathers. On the coast of Pernambuco, high density values of Ostreopsis cf. ovata were found by Machado (2015) in a reef area in Porto de Galinhas beach, in the south coast of the state. De' Carli (2014) recorded the dominance and high abundance values of Ostreopsis cf. ovata followed by P. lima in the same location.
Records of blooms of Ostreopsis cf. ovata were also reported in the oceanic region by Nascimento et al. (2012), with a mean density of 4.6 $\mathrm{x} 10^{4}$ cells per wet weight of the macroalgae Laurencia sp. in the Archipelago of Saint Paul's Rocks.

The macroalgae collected on the studied beaches did not present a clear seasonality; they only differed in terms of dominant phyla. At Pina beach, the phylum Chlorophyta predominated. As this phylum is a bioindicator of organic pollution, our findings indicate the strong action of anthropic factors in the area. Reis and Yoneshigue-Valentin (1998) describe the genus Ulva as opportunistic and tolerant to wide variations of environmental parameters, adapting very well to more eutrophic regions. Thus, our findings on the dominance of Ulva sp., as also reported in past works carried out in the same area (Sousa \& Concentino 2004, Vasconcelos 2012), confirm that Pina beach is an area of consolidated urbanization.

The dominance of macroalgae of the Phaeophyta and Rhodophyta phyla at Pedra de Xaréu beach characterize the environment as an area of lesser action of anthropic factors and water stress, with a constant beating of waves and greater water circulation (Cutrim 1990, Sousa \& Concentino 2004).

According to Taylor (1985), Lobel et al. (1988), and Bomber et al. (1989), epiphytic dinoflagellates show preferences for threedimensional algae with flexible surfaces and high surface areas rather than particular macroalgae phyla or species.

However, although epiphyte abundance was associated with the algae $H$. musciformes and Sargasssum sp., no significant relationships were found as to the preference of the epiphytes for given macroalgae. Popowski (1994) also observed that epiphytic dinoflagellates did not show a preference for any specific substrate in Cuban waters. According to Vila et al. (2001), no significant relationship was found between macroalgae and the 3 dominant species of dinoflagellates studied. Okolodkov et al. (2007) also said that most epiphytic dinoflagellates found in the Veracruz reef zone in the Gulf of Mexico did not show any particular preference for macrophyte species.

The species Ulva sp. (Chlorophyta) and Padina sp. (Phaeophyta) showed high richness and abundance of epiphytes despite their foliose thalli, with a greater diversity of species observed in the thalli of Padina sp., in agreement with a study by 
Delgado et al. (2006), who observed most of the epiphytes to be associated with this macroalgae.

The association of these species with foliaceous thalli with epiphytic dinoflagellates may be related to both the morphofunctional structure of their thalli and their dominance in the collection site, due to favorable conditions.

In conclusion, it can be said that the dinoflagellate community presented high richness but low diversity of species, being influenced by the dominance of S. spinifera and Gymnodinium sp., on Pina beach.

Favorable environmental conditions, such as high temperature, salinity and low phosphate contents, at Pedra de Xaréu beach, favored the abundance of potentially toxic dinoflagellates, Ostreopsis cf. ovata and P. lima. The dominant species Ostreopsis cf. ovata, exclusive to Pedra de Xaréu beach, was inversely correlated with nutrient levels, and the significant variation in phosphate contents proved the difference in anthropogenic impact on the studied beaches, highlighting the presence and absence of some species of dinoflagellates in macroalgae. In addition, characteristics of the dry period showed a strong influence on the epiphytes. Although higher abundance peaks were observed on $H$. musciformes and Sargassum sp., there was no significant preference of the epiphytes for a certain macroalgae species. Thus, given the occurrence of potentially toxic species and the possible problems that these species can cause, further studies and constant monitoring on the beaches of the coast of Pernambuco are necessary.

\section{Acknowledgments}

To the Oceanography Department for providing structural and technical support, allowing the use of all facilities, and to the technicians from LABFITO, LOQUIM and Marine Macroalgae Laboratory, who helped in the laboratory and field work.

\section{Financial Support}

The research was supported by the Coordination for the Improvement of Higher Education Personnel (CAPES) through a doctoral scholarship to the first author for the development of the doctoral project.

\section{References}

Accioly, M. C. 1992. Metodologia de amostragem e zonação das comunidades bentônicas do costão rochoso da praia de Pedra do Xaréu Estado de Pernambuco (Brasil). Dissertação de Mestrado. Universidade Federal Rural de Pernambuco, Recife, Brasil, 146 p.

Anderson, D. M., Glibert, P. M. \& Burkholder, J. M. 2002. Harmful algal blooms and eutrophication: nutrient sources, composition and consequences. Estuaries, 25(4b): 704726.

Andrade, G. O. \& Lins, R. C. 1971. Os climas do Nordeste. Pp. 95-138. In: Vasconcelos Sobrinho, J. (Ed.). As regiões naturais do Nordeste, o meio e a civilização. CONDEPE, Recife, $442 \mathrm{p}$.

Aragão, J. O. R. A. 2004. Influência dos oceanos Pacífico e Atlântico na dinâmica do tempo e do clima do Nordeste do Brasil. pp.145-160. In: E. Eskinazi-Leça et al. (ed.). Oceanografia: um cenário tropical. Editora Bagaço, Recife, Brasil.

Balech, E. 1988. Los dinoflagelados del Atlântico Sudoccidental. Instituto Español de Oceanografia, Madrid, $310 \mathrm{p}$.

Bomber, J. W., Tindall, D. R. \& Miller, D. M. 1989. Genetic variability in toxin potencies among seventeen clones of Gambierdiscus toxicus (Dinophyceae). Journal of Phycology, 25(4): 617-625.

Bower, C. E. \& Holm-Hansen, T. 1980. A salicylatehypochlorite methodfor determining ammonia in seawater. Canadian Journal of Fisheries and Aquatic Sciences, 37: 794-798.

Carlson, R. D. \& Tindall, D. R. 1985. Distribution ad periodicity of toxic dinoflagellates in the Virgin Islands. Pp. 171-176. In: Anderson, D. M., White, A. W. \& Baden, D. G. (Eds). Toxic Dinoflagellates. New York, Elsevier, 561 p.

Cembella, A. D. 2003. Chemical ecology of eukaryotic microalgae in marine ecosystems. Phycologia, 42: 420-44.

Chung, M. H. \& Lee, K. S. 2008. Species composition of the epiphytic diatoms on the leaf tissues of three Zostera species distributed on the southern coast of Korea. Algae, 23: 75-81.

Cohu, S., Thibaut, T., Mangialajo, L., Labat, J. P., Passafiume, O., Blanfuné, A., Simon, N., Cottalorda, J. M. \& Lemée, R. 2011. Occurrence of the toxic dinoflagellate Ostreopsis cf. ovata in relation with environmental factors in Monaco (NW Mediterranean). Marine Pollution Bulletin, 62: 2681-2691. 
Cohu, S., Mangialajo, L., Thibaut, T., Blanfune, A. \& Marro, S. 2013. Proliferation of the toxic dinoflagellate Ostreopsis cf. ovata in relation to depth, biotic substrate and environmental factors in the North West Mediterranean Sea. Harmful Algae, 24: 32-44.

Costa, C. F., Amaral, F. D., Sassi, R. \& EskinaziLeça, E. 2001. Some diatoms attached to scleractinian corals from northeast Brazil. Revista Nordestina de Biologia, 15(1): 2330.

Costa, M. M. S., Pereira, S. M. B., Arruda, P. C. \& Eskinazi-Leça, E. 2014. Quantitative variation of epiphytic diatoms in Galaxaura rugosa (Nemaliales: Rhodophyta). Marine Biodiversity Records, 7: e85.

Costa, M. M. S., Pereira, S. M. B., Silva-Cunha, M. G. G., Arruda, P. C. \& Eskinazi-Leça, E. 2016. Community structure of epiphytic diatoms on seaweeds in Northeastern Brazil. Botanica Marina, 59(4): 231-240.

Cutrim, M. V. J. 1990. Distribuição das macroalgas na região entre-marés do recife da praia de Piedade, município Jaboatão dos Guararapes (Estado de Pernambuco - Brasil). Dissertação de Mestrado. Universidade Federal Rural de Pernambuco, Recife, Brasil, 135p.

De'Carli, G. A. L. 2014. Distribuição e abundância de dinoflagelados epi-bentônicos na costa nordeste no Brasil. Dissertação de Mestrado. Universidade Federal do Estado do Rio de Janeiro, Rio de Janeiro, Brasil, 35 p.

Delgado, G., Lechuga-Devéze, C. H., Popowski, G., Troccoli, L. \& Salinas, C. A. 2006. Epiphytic dinoflagellates associated with ciguatera in the northwestern coast of Cuba. Revista de Biologia Tropical, 54(2): 299-310.

Dickson, A.G., Sabine, C.L. \& Christian, J.R. 2007. Guide to best practices for ocean $\mathrm{CO} 2$ measurements. PICES Special Publication, p. 191.

Diogéne, G., Durand-Clement, M. \& Puiseux-Dao, S. 1992. La ciguatera intoxication alimentaire d'origine marine et la maïtotoxine composante du complexe toxinique ciguatérique. Revue Scientifique et Technique, 2: 37-47.

Eskinazi-Leça, E., Magalhães, K. M. \& Moura Junior, A.M. 2003. Variação quantitativa da diatomoflora epífita na fanerógama marinha Halodule wrightii Aschers. no litoral de Pernambuco. VI Congresso de Ecologia do Brasil, 2: 270-271.
Faust, M. A., Larsen, J. \& Moestrup, Ø. 1999. Potentially toxic phytoplankton. 3. Genus. Prorocentrum (Dinophyceae), ICES Identification Leaflets for Plankton, 184: 123.

Ferreira, C. E. L. 2006. Sea urchins killed by toxic algae. JMBA Global Marine Environment, (3): 23-24.

Ferreira, L. C., Silva Cunha, M. G. G., Koening, M. L., Feitosa, F. A. N., Santiago, M. F. \& Muniz, K. 2010. Variação Temporal do Fitoplâncton em Três Praias Urbanas do Litoral Sul do Estado de Pernambuco, Nordeste do Brasil. Acta Botanica Brasilica, 24(1): 214-224.

Gillespie, N. C., Holmes, M. J., Burke, J. B. \& Doley, J. 1985. Distribution and periodicity of Gambierdiscus toxicus in Queensland, Australia. Pp. 183-188. In: Anderson, D. M., White, A. \& Baden, D. (Eds.). Toxic dinoflagellates. Elsevier Science, 561 p.

Gómez, A. 2009. Dinofagelados bentónicos potencialmente tóxicos asociados a moluscos bivalvos de importancia comercial en algunas localidades del Estado Nueva Esparta. Trabajo de grado. La Asunción: Escuela de Ciencias Aplicadas del Mar, Universidad de Oriente; $47 \mathrm{p}$.

Gómez Del Prado, R. M. C., Valles, V. I., Lozano, C. H. \& Hernández, T. S. 2011. Metacercariae of hemiurid in copepods from the Ensenada de la Paz, Baja California Sur, Mexico. Neotropical Helminthology, 5(2): 125-137.

Granéli, E., Ferreira, C. E. L., Yasumoto, T., Rodrigues, E. \& Neves, M. H. B. 2002. Sea urchins poisoning by the benthic dinoflagellate Ostreopsis cf. ovata on the Brazilian coast. 10th International Conference on Harmful Algae, St. Petersburg, Florida, EUA. 113 p.

Grasshoff, F. K., Emrhardt, M. \& Kremling, K. 1983. Methods of sea water analysis. Second Edition. New York: Verlag Chemie. 419 p.

Grzebyk, D., Berland, B., Thomassin, B. A., Bosi, C. \& Arnoux, A. 1994. Ecology of ciguateric dinoflagellates in the coral reef complex of Mayotte Island (S.W. Indian Ocean). Journal of Experimental Marine Biology and Ecology, 178: 51-66.

Guerra, N. C. \& Manso, V. A. V. 2004. Beachrocks (Recifes de Arenito). Pp. 109-130. In: Eskinazi-Leça, E., Neumann-Leitão, S. \& Costa M. F. (Org.). Oceanografia: Um Cenário Tropical. Recife: Ed. Bagaço, 761 p. 
Hallegraeff, G. M. 1993. A review of harmful algal blooms and their apparent global increase. Phycologia, 32(2): 79-99.

Hauxwell, J., Cebrián, J., Furlong, C. \& Valiela, I. 2001. Macroalgal canopies contribute to eelgrass (Zostera marina) decline in temperate estuarine ecosystems. Ecology, 82: 1007-1022.

Heisler, J., Glibert, P. M., Burkholder, J. M., Anderson, D. M., Cochlan, W., Dennison, W. C., Dortch, Q., Gobler, C. J., Heil, C. A., Humphries, E., Lewitus, A., Magnien, R., Marshall, H. G., Sellner, K., Stockwell, D. A., Stoecker, D. K. \& Suddleson, M. 2008. Eutrophication and harmful algal blooms: a scientific consensus. Harmful Algae, 8: 3-13.

Hill, M., Allenby, A., Ramsby, B., Schönberg, C. \& Hill, A. 2011. Symbiodinium diversity among host clionaid sponges from Caribbean and Pacific reefs: Evidence of heteroplasmy and putative host-specific symbiont lineages. Molecular Phylogenetics and Evolution, 59: 81-88.

Hoppenrath, M., Elbrachter, M. \& Drebes G. 2009. Marine Phytoplankton: Selected microphytoplankton species from the North Sea around Helgoland and Sylt. Germany: E. Schweizerbart'sche Verlagsbuchhandlung (Nagele u. Obermiller), Stuttgart. $264 \mathrm{p}$.

Kim, H.S., Yih, W., Kim, J.H., Myung, G. \& Jeong, H.J. 2011. Abundance of epiphytic dinoflagellates from coastal waters off Jeju Island, Korea during Autumn 2009. Ocean Science Journal. 46 (3) 205-209.

Koening, M. L. \& Macêdo, S. J. 1999. Hydrology and Phytoplankton Community Structure at Itamaracá-Pernambuco (Northeast, Brazil). Arquivos de Biologia e Tecnologia, 42(4): 381-392.

Koening, M. L. \& Lira, C. G. 2005. O gênero Ceratium Schrank (Dinophyta) na plataforma continental e águas oceânicas do estado de Pernambuco, Brasil. Acta Botanica Brasílica, 19(2): 391-397.

Kraberg, A., Baumann, M. \& Durselen, C. D. 2010. Coastal Phytoplankton: Photo Guide for Northern European Seas. Verlag Dr. Friedrich Pfeil, Munchen, Germany. 204 p.

Lassus, P. 1988. Plancton toxique et plancton d'eaux rouges sur les cotes europeennes. Institut Français de Recherche Pour l'
Exploitation de la Mer IFREMER, Brest, 108 p.

Laza-Martinez, A., Orive, E. \& Miguel, I. 2011. Morphological and genetic characterization of benthic dinoflagellates of the genera Coolia, Ostreopsis and Prorocentrum from the southeastern Bay of Biscay. The European Journal of Phycology, 46(1): 45-65.

Lobel, P. S., Anderson, D. M. \& Durand-Clement, M. 1988. Assessment of ciguatera dinoflagellate populations: sample variability and algal substrate selection. Biology Bulletin, 175: 94-101.

Macêdo, S. J.; Muniz, K. \& Flores-Montes, M. J. 2004. Hidrologia da região costeira e plataforma continental do estado de Pernambuco, Pp. 255-286. In: Eskinazi-Leça, E., Neumann-Leitão, S. \& Costa, M. F. (Eds). Oceanografia, um cenário tropical. Recife, Bagaço, 761p.

Machado, R. C. A. 2015. Estrutura da comunidade fitoplanctônica e hidrologia do ecossistema recifal de porto de galinhas (PernambucoBrasil). Tese de Doutorado. Universidade Federal de Pernambuco, Recife, Brazil

Macintyre, H. L., Geider, R. J. \& Miller, D. C. 1996. Microphytobenthos: The ecological role of the "secret garden" of unvegetated, shallowwater marine habitats 1. Distribution, abundance and primary production. Estuaries, 19: 186-201.

Mangialajo, L., Ganzin, N., Accoroni, S., Asnaghi, V., Blanfuné, A., Cabrini, M., Cattaneo-Vietti, R., Chavanon, F., Chiantore, M., Cohu, S., Costa, E., Fornasaro, D., Grossel, H., MarcoMiralles, F., Masó, M., Reñé, A., Rossi, A. M., Sala, M., Thibaut, T., Totti, C., Vila, M. \& Lemée, R. 2011. Trends in Ostreopsis proliferation along the Northern Mediterranean coasts. Toxicon, 57: 408-420.

Marcano, A. 2011. Dinofagelados bentónicos potencialmente tóxicos asociados a los epibiontes del mangle rojo Rhizophora mangle Linnaeus (1753) en la laguna de la Restinga, Isla de Margarita, Estado Nueva Esparta. Trabajo de grado. La Asunción: Escuela de Ciencias Aplicadas del Mar, Universidad de Oriente, 63 p.

Marchan-Álvarez, J., Valerio-González, L., TroccoliGhinaglia, L. \& Monroy, F.L. 2017. Dinoflagelados bentónicos nocivos, asociados con el sedimento arenoso en dos playas de la 
isla de Margarita. Venezuela. Revista de Biodiversidad Neotropical, 7 pp. 156-168 Margalef, R. 1978. Perspectivas de la teoria ecológica. Barcelona: Editoral Blume, 110 p.

Melo, M. A. F., Koening, M. L., Souto, J., Travassos, R. K., Silva, A. C. 2014. Microfitoplâncton de águas costeiras adjacentes ao Porto do Recife (PE-Brasil). Tropical Oceanography, Recife, 42, p. 80-94.

Menezes, M., Varela, D., Proença, L. A. O., Paredes, J. \& Schramm, M. A. 2010. Morphology and molecular characterization of Ostreopsis (Dinophyceae) isolates from Northeastern Brazil. In: 14th International Conference on Harmful Algae. Hersonissos (Grécia) (Abstract).

Moreira, A., Rodríguez, F., Riobó, P., Franco, J. M., Martínez, N., Chamero, D., Alonso, C. 2012. Notes on Ostreopsis sp. from SouthernCentral Coast of Cuba. Cryptogamie, Algologie, 33(2): 217-224.

Muñoz, A. O. M. 1993. Aspectos ecológicos da margem de Sargassum do costão rochoso da praia de Pedra do Xaréu - PE - Brasil. Dissertação de Mestrado. Universidade Federal Rural de Pernambuco, Recife, Brasil, $82 \mathrm{p}$.

Nascimento, S. M. \& Corrêa, E. V. 2010. Influence of temperature on growth parameters of Ostreopsis cf. ovata, Prorocentrum cf. maculosum, Coolia monotis and Amphidinium sp. strains from Rio de Janeiro, Brazil. In: GEOHAB “Open Science Meeting on Harmful Algal Blooms in Benthic Systems", Honolulu, Hawaii.

Nascimento, S. M., França, J. V., Gonçalves, J. E. A. \& Ferreira, C. E. L. 2012. Ostreopsis cf. ovata (Dinophyta) bloom in an equatorial island of the Atlantic Ocean. Marine Pollution Bulletin, 64: 1074-1078.

Nimer, E. 1989. Climatologia do Brasil. Secretaria de Planejamento e Coordenação da Presidência da República e IBGE, Rio de Janeiro 421p.

Okolodkov, Y. B., Campos-Bautista, G., GarateLizarraga, I., Guillermo Gonzales-Gonzales, J. A., Hoppenrath, M. \& Arenas, V. 2007. Seasonal changes of benthic and epiphytic dinoflagellates in the Veracruz reef zone, Gulf of Mexico. Aquatic Microbial Ecology, 47: 223-237.

Okolodkov, Y. B., Merino-Virgilio, F. M., AkéCastillo, J. A., Aguilar-Trujillo, A. C.,
Espinosa-Matías, S. \& Herrera-Silveira, J. A. 2014. Seasonal changes in epiphytic dinoflagellate assemblages near the Northern Coast of the Yucatan Peninsula, Gulf of Mexico. Acta Botanica Mexicana, 107: 121151.

Orla. Projeto. 2001. Brasília: Ministério do Meio Ambiente e Ministério do Planejamento, Orçamento e Gestão.

Pacobahyba, L. D., Eskinazi-Leça, E., Silva-Cunha, M. G. G. \& Koening, M. L. 1991. Diatomáceas (Bacillariophyceace) epífitas na fanerógama marinha Halodule wrightii Aschers. (Cymodoceaceae). Trabalhos Oceanográficos da Universidade Federal de Pernambuco, 22: 39-63.

Papaspyrou S., Smith, C. J., Dong, L. F., Whitby, C., Dumbrell, A. J. \& Nedwell, D. B. 2014. Nitrate reduction functional genes and nitrate reduction po-tentials persist in deeper estuarine sediments. Why? PLoS One, 9: e94111.

Parsons, M. L. \& Preskitt, L. B. 2007. A survey of epiphytic dinoflagellates from the coastal waters of the island of Hawaii. Harmful Algae, 6: 658-669.

Passavante, J. Z. O. 1979. Contribuição ao estudo dos dinoflagelados da Plataforma Continental de Pernambuco-Brasil. Trabalhos Oceanográficos da Universidade Federal de Pernambuco, 14: 31-54.

Pearce, I., Marshal, J. \& Hallegraeff, G. M. 2000. Toxic Epiphytic Dinoflagellates from East Coast Tasmania, Australia. Pp. 54-57. Proceedings of the 9th International Conference - Harmful Algal Blooms.

Pezzolessi, L., Guerrini, F., Ciminiello, P., Dell'Aversano, C., Iacovo, E. D., Fattorusso, E., Forino, M., Tartaglione, L. \& Pistocchi, R. 2012. Influence of temperature and salinity on Ostreopsis cf. ovata growth and evaluation of toxin content through HR LC-MS and biological assays. Water Research, 46: 8292.

Pielou, E. C. 1967. Mathematical ecology. New York: Wiley.

Popowski, G. 1994. Dinoflagelados asociados con la ciguatera en aguas cubanas. In: VII Reunión Nacional de la Sociedad Mexicana de Planctología, A.C. Resúmenes. La Paz, Baja California Sur.

Reis, R. P. \& Yoneshigue-Valentin, Y. 1998. Variação espaço-temporal de populações de Hypnea 
musciformis (Rhodophyta, Gigartinales) na baía de Sepetiba e Armações dos Búzios, RJ, Brasil. Acta Botanica Brasílica, 12: 465-483.

Rhodes, L., Adamson, J., Suzuki, T., Briggs, L. \& Ian, G. 2000. Toxic marine epiphytic dinoflagellates, Ostreopsis siamensis and Coolia monotis (Dinophyceae), in New Zealand. New Zealand Journal of Marine and Freshwater Research, 34: 371-383.

Selina, M. S., Morozova, T. V., Vyshkvartsev, D. I. \& Orlova, T. Y. 2014. Seasonal dynamics and spatial distribution of epiphytic dinoflagellates in Peter the Great Bay (Sea of Japan) with special emphasis on Ostreopsis species. Harmful Algae, 32: 1-10.

Shannon, C. E. \& Weaver, W. 1963. The mathematical theory of communication. Urbana, University of Illinois Press. 173 p.

Shears, N. T. \& Ross, P. M. 2009. Blooms of benthic dinoflagellates of the genus Ostreopsis; an increasing ecologically important phenomenon on temperate reefs in New Zeland and worldwide. Harmful Algae, 8: 916-925.

Sournia, A. 1978. Phytoplankton Manual. Paris, UNESCO (United Nations Educational, Scientific and Cultural Organization) (Monographs on oceanographie methodology, $6)$.

Sousa, G. S. \& Cocentino, A. L. M. 2004. Macroalgas como Indicadoras da qualidade ambiental da Praia de Piedade - PE. Tropical Oceanography, 32(1): 1-22.

Strickland, J. D. H. \& Parsons, T. R. 1972. A practical handbook of sea water analysis. Journal of the Fisheries Research Board of Canada, 167: 207-211.

Taylor, F. J. R. 1985. The distribution of the dinoflagellate Gambierdiscus toxicus in the Eastern Caribbean. Pp. 423-428. In: Gabrie, C. \& Salvat, B. (Eds.). Proceedings Of the Fifth International Coral Reef Congress, 4 Symposia and Seminars.

Tibiriçá, C. E. J. A., Proença, L. A. O. \& Schramm, M. A. 2010. Investigação da ocorrência de dinoflagelados epífitos em duas enseadas na região Centro-Norte de Santa Catarina. In.: XIII Congresso Brasileiro de Ficologia, Paraty, RJ.

Tomas, C. R. 1997. Identifying marine phytoplankton. San Diego: Academic press. $858 \mathrm{p}$.

Totti, C., Poulin, M., Romagnoli, T., Perrone, C., Pennesi, C. \& De Stefano, M. 2009. Epiphytic diatom communities on intertidal seaweeds from Iceland. Polar Biology, 32: 1681-1691.

Totti, C., Accoroni, S., Cerino, F., Cucchiari, E. \& Romagnoli, T. 2010. Ostreopsis cf. ovata bloom along the Conero Riviera (northern Adriatic Sea): Relationships with environmental conditions and substrata. Harmful Algae, 9: 233-239.

Utermohl, H. 1958. Zur Vervollkommnung der quantitativen Phytoplankton- ethodik. Mitt. Int. Ver. Limnology, 9: 1-38.

Vasconcelos, E. R. T. P. P. 2012. Índice de distúrbio ambiental (IDA) através das macroalgas marinhas bentônicas dos recifes areníticos de Pernambuco. Dissertação de Mestrado. Universidade Federal de Pernambuco, Recife, Brasil, 60 p.

Vasconcelos, E. R. T. P. P. 2016. Macroalgas marinhas como ferramenta de avaliação do estado de conservação de ambientes recifais em Pernambuco. Tese de Doutorado. Universidade Federal de Pernambuco, Recife, Brasil, 133 p.

Vila, M., Garcés, E. \& Masó, M. 2001. Potentially toxic epiphytic dinoflagellate assemblages on macroalgae in the NW Mediterranean. Aquatic Microbial Ecology, 26: 51-60.

Wetzel, R. G \& Likens, G. E. 2000. Limnological analyses. 3 ed. Springer-Verlag, New York. $429 \mathrm{p}$.

Wright, J. L. C. \& Cembella, A. D. 1998. Ecophysiology and biosynthesis of polyether marine biotoxin. Pp. 427-452. In: Physiological ecology of harmful algal blooms, Anderson, D. M., Cembella, A. D. \& Hallegraeff, G. M. (Eds.), Springer, Berlin.

Received: August 2021

Accepted: October 2021

Published: November 2021 